\title{
Meme kanserinde serum matriks metalloproteinaz 2-7-9, doku matriks metalloproteinaz inhibitörü 1, vasküler endotelial büyüme faktörü, interlökin 6 ve interlökin 8 düzeylerinin değerlendirilmesi
}

\author{
Evaluation of serum matrix metalloproteinase 2-7-9, tissue matrix metalloproteinase \\ inhibitor 1, vascular endothelial growth factor, interleukin 6 and interleukin 8 levels in \\ breast cancinoma
}

Serkan Değirmencioğlu, Aydın Demiray, Atike Gökçen Demiray, Burcu Taşköylü, Gamze Gököz Doğu

Gönderilme tarihi:03.12.2018

Kabul tarihi:03.01.2019

Özet

Amaç:Meme kanseri insidansının artması ve gelişen tedaviler ile sağkalımın uzaması izlemde yeni belirteçlere gereksinim ortaya çıkarmaktadır. Serum matriks metalloproteinaz 2, 7, 9 (MMP2, MMP7, MMP9), doku matriks metalloproteinaz inhibitörü1 (TIMP1), interlökin 6, interlökin 8 ve vasküler endoteliyal büyüme faktörü (VEGF) kanserogenezin farklı basamaklarında rol almaktadırlar. Çalışmamızın amacı meme kanseri hastalarında bu parametrelerin klinik evre, histopatolojik özellikler ve laboratuar değerleri üzerine etkilerini değerlendirmektir.

Gereç ve Yöntem: Meme kanseri patolojik tanısı konmuş kemoterapi naif yetmiş sekiz kadın hasta çalışmaya alındı. İstatistik, Statistical Package for Social Sciences version15 ile hesaplandı. Sonuçlar \%95 güven aralığında değerlendirildi. $p<0,05$ olması istatistiksel olarak anlamlı kabul edildi. Hasta gruplarını karşılaştırmalarında kikare ve Mann Whitney-U testi uygulandı.

Bulgular: Hastaların medyan yaşı $52 \pm 11,6$ bulundu. Hastalar "non-metastatik" ve "metastatik" şeklinde iki gruba ayrıldı. Metastatik grupta serum VEGF değeri 3,4 kat yüksek saptandı. Serum CA15-3 seviyesinde yükselme, artmış MMP9 ve IL6 seviyeleri ile anlamlı ilişkiliydi. Serum LDH seviyesi artmış hastalarda serum VEGF ve TIMP1 seviyeleri anlamlı arttı. Serum CRP artışı IL8, IL6 ve MMP9 artışı ile ilişkili bulundu. Serum VEGF seviyeleri progrese olgularda yüksekti. İzlemde kaybedilen hastaların serum VEGF seviyesi daha yüksek olmakla beraber istatistiksel anlamlı değildi. Hormon pozitif grupta negatif gruba göre serum MMP7 seviyeleri anlamlı düşük saptandı. HER2 (3+) hasta grubunda serum MMP2 seviyeleri HER2 $(0 / 1+/ 2+)$ hasta grubuna göre daha yüksekti. Serum TIMP1 seviyesi ki 67 oranı $\% 40$ ve üzeri hastalarda, oran $\% 40$ altında olan hastalara göre anlamlı düşük bulundu.

Sonuç: Çalışmamız kısıtı hasta sayısı ile yapılan kısa takip süresine sahip bir ön çalışma özelliğindedir.

Anahtar Kelimeler: Meme kanseri, VEGF, IL6, IL8.

Değirmencioğlu S, Demiray A, Demiray AG, Taşköylü B, Gököz Doğu G. Meme kanserinde serum matriks metalloproteinaz 2-7-9, doku matriks metalloproteinaz inhibitörü 1, vasküler endotelial büyüme faktörü , interlökin 6 ve interlökin 8 düzeylerinin değerlendirilmesi. Pam Tıp Derg 2019;12:261-267.

\footnotetext{
Abstract

Purpose:The increased incidence of breast cancer and development of new treatment modalities improved significant survival so new markers are needed for better assesment and follow up. Serum matrix metalloproteinase 2, 7, 9 (MMP2, MMP7, MMP9), tissue matrix metalloproteinase inhibitor 1 (TIMP1), interleukin 6, interleukin 8 and vascular endothelial growth factor (VEGF) take different parts in carcinogenesis. The aim of this study was to evaluate the relationship between these markers and clinical stage, histopathologic features and laboratuary parameters.

Materials and Methods: Seventy-eight pathologically proven, chemotherapy naive breast cancer patients were enrolled. The analyses were carried out using SPSS v15 and $p<0.05$ was accepted as significant. Descriptive studies were analyzed using chi-square test and Mann-Whitney U-test depending on group numbers.

Serkan Değirmencioğlu Dr. Öğr. Üyesi, Pamukkale Üniversitesi Medikal Onkoloji Bilim Dalı, DENiZLí, e-posta: drserkandeg@ hotmail.com (orcid.org/0000-0002-1213-2778) (Sorumlu yazar).

Aydın Demiray, Dr. Öğr. Üyesi, Pamukkale Üniversitesi Tıbbi Genetik Bilim Dalı, DENizLí, e-posta: ademiray@pau.edu.tr (orcid.org/0000-0002-3343-0184).

Atike Gökçen Demiray, Dr. Öğr. Üyesi, Pamukkale Üniversitesi Medikal Onkoloji Bilim Dalı, DENiZLi, e-posta: agakaslan@ pau.edu.tr (orcid.org/0000-0003-4397-5468).

Burcu Taşköylü, Dr. Öğr. Üyesi, Pamukkale Üniversitesi Medikal Onkoloji Bilim Dalı, DENiZLí, e-posta: btaskoylu@pau.edu. tr (orcid.org/0000-0003-4755-2753).

Gamze Gököz Doğu, Prof. Dr, Pamukkale Üniversitesi Medikal Onkoloji Bilim Dalı, Denizli, e-posta: ggokoz@pau.edu.tr (orcid.org/0000-0001-8142-0362).
} 
Results: The median age of patients were $52 \pm 11.6$ years. Patients were divided into non-metastatic and metastatic groups. VEGF values were 3.4 fold higher in metastatic group. Higher CA15-3 levels were statistically correlated with MMP9 and IL6. The elevation of serum LDH were associated with elevated VEGF and TIMP1. CRP elevation was correlated with increased IL8, IL6 and MMP9. High levels of VEGF was associated with progression. VEGF levels of dead patients were higher although the difference was not significant. MMP7 levels were lower in hormon positive group while the MMP2 levels were higher in HER2 (3+) group. TIMP1 levels were lower in patients with a ki 67 ratio above $40 \%$.

Conclusion: This is the first study showing the correlation between serum MMP2 levels and HER2 positivity, and also the negative correlation between ki67 and serum TIMP1 levels. This preliminary study was performed with limited number of patients although shown the potential effect of new biomarkers in clinical prognosis of breast carcinoma.

Key Words: Breast cancer, VEGF, IL6, IL8.

Değirmencioğlu S, Demiray A, Demiray AG, Taşköylü B, Gököz Doğu G. Evaluation of serum matrix metalloproteinase 2-7-9, tissue matrix metalloproteinase inhibitor 1, vascular endothelial growth factor, interleukin 6 and interleukin 8 levels in breast cancinoma. Pam Med J 2019;12:261-267.

\section{Giriş}

Meme kanseri tüm dünyada kadınlarda en sık görülen kanser olup 35-39 yaş arası kadınlarda en sık kanser ölüm nedenidir. Her sekiz kadından biri yaşamı boyunca meme kanseri olacağı gibi tüm dünyada her yıl 1,3 milyon meme kanserine bağlı ölüm gerçekleşmektedir [1]. Meme kanserogenezinde bazal membranın proteolitik degradasyonu tümör proliferasyonu ve metastaz için temel oluşturur. Çeşitli matriks metalloproteinazlar (MMP) ve onlara yanit veren doku matriks metalloproteinaz inhibitörleri (TIMP) bu süreçte rol alır [2]. Kollejenazlar, jelatinazlar, stromelizinler ve membran tipi MMP olmak üzere yirmiden fazla insan MMP türü bulunmaktadır [3]. Damar bazal membranının önemli bir bileşeni olan tip 4 kollajeni degrade etme yeteneği bulunan tip 2 ve 9 MMP, metastaz patogenezinde dikkat çekmektedir [4]. Akciğer ve kolon kanserinde MMP2 ekspresyonu kullanışlı bir prognostik belirteç olarak kabul edilmiştir $[5,6]$. MMP2 aktivasyonu ve enzimatik aktivitesi TIMP2 tarafından kontrol edilir [7]. MMP7 ise MMP2 ve MMP9 aktive ederek tip 4 kollajeni de içeren ekstraselüler matriks yıkımında başrolü üstlenir [8]. MMP7 salınımının tümör hücrelerinin transformasyonu sonucu gerçekleştiği üzerinde durulmaktadır. Bu nedenle MMP inhibitörlerinin kanser tedavisinde etkili olması beklenmektedir [9]. Yapılan çalışmalar metastatik kolon karsinomunda TIMP-1 RNA seviyesinin nonmetastatik olgulara göre daha yüksek olduğunu göstermektedir [10].
Enflamasyonda görevli sitokinler aynı zamanda tümör hücre proliferasyonunda da rol almaktadırlar. IL-6 hem pro hem de anti-enflamatuvar özellikli bir sitokindir. Ayrıca in vitro ortamda antitümör etkinliği de tanımlanmıştır [11]. IL-8 ise pro-inflamatuvar bir sitokin olmasının yanında potansiyel bir immün hücre aktivatörüdür. IL-8, tümör hücre mitozunu aktive ederken tümör anjiyogenezinde de etki gösterir [12]. Hormon reseptör durumundan bağımsız olarak meme kanseri hastalarında serum IL-6 ve IL-8 seviyeleri klinik evre ile korelasyon göstermiştir [13]. Bachelot ve ark. çalışmalarında serum IL-6 düzeyini meme kanseri tüm sağ kalımında bağımsız prognostik faktör olarak bildirmiştir [14]. VEGF, vasküler geçirgenliği arttırarak endotel hücre mitozunu tetiklemektedir. Li ve ark. meme kanseri dokusunda yüksek VEGF ekspresyonunun düşük sağ kalım ile ilişkisini göstermişlerdir [15].

Meme kanserinde gelişen tedavi modaliteleri ile sağ kalım süresinin giderek uzaması bu hastaların izleminde yeni belirteçlere gereksinim ortaya çıkarmaktadır. Serum matriks metalloproteinaz 2, 7, 9 (MMP 2, MMP 7, MMP 9), doku matriks metalloproteinaz inhibitörü 1 (TIMP 1), interlökin 6 , interlökin 8 ve vasküler endoteliyal büyüme faktörü (VEGF) kanserogenezin farklı basamaklarında rol almaktadırlar. Çalışmamızın amacı meme kanseri hastalarının tanı anıdaki serum MMP 2-7-9, TIMP 1, IL 6-8 ve VEGF seviyelerinin klinik evre, histopatolojik özellikler, laboratuar parametreleri ve sağ kalım süreleri ile ilişkilerini değerlendirmektir. 


\section{Gereç ve yöntem}

Histopatolojik olarak meme kanseri tanısı konularak kliniğimize başvuran kemoterapi naif 78 kadın hasta çalışmaya dahil edildi. Değerlendirilen biyobeliteçleri etkileme potansiyeli olan kronik hastalıklara sahip hastalar (Diyabet, romatoid artrit, enflamatuvar barsak hastalıkları, sistemik lupus eritematozus) çalışmaya dahil edilmedi. Pamukkale Üniversitesi Girişimsel olmayan araştırmalar etik kurulu onayı alındı. Katılımcı hastalardan bilgilendirilmiş onam formları alındı. Hasta grubunu oluşturan bireylerin en az 8 saatlik gece açlığını takiben sabah aç karnına kan örnekleri kemoterapiye başlamadan önce alındı. Ayrıca topluca çalışılacak olan MMP 2-7-9, TIMP 1, IL 6-8 ve VEGF için $6 \mathrm{ml}$ venöz kan örnekleri vakumlu düz tüplere alınarak, 10 dakika 15000 rpm'de santrifüj edilerek serum kısmı ayrılıp $-70^{\circ} \mathrm{C}$ de derin dondurucuda saklandı. ELISA (Enzyme-Linked Immunosorbent Assay) yöntemi (Digital and analog system, DAS, Plombara Sabina Italy) ile serum MMP 2-7-9, TIMP 1, IL 6-8 ve VEGF ölçüldü. Hastaların demografik verilerine hasta dosyalarından, laboratuar parametrelerine de hastane bilgi sisteminden ulaşıldı.

Serum MMP 2-7-9, TIMP 1, IL 6-8 ve VEGF cut-off değerleri, Statistical Package for Social Sciences version 15.0 (SPSS-15.0, for windows) paket programı ile hesaplandı. Cutoff değerlerine eşit ve altındakiler seviyeler "düşük", üstündeki seviyeler ise "yüksek" olarak değerlendirildi. İstatistiksel analiz, aynı paket programı ile yapıldı. Sonuçlar \%95 güven aralığında değerlendirildi. $p<0,05$ olması durumunda istatistiksel olarak anlamlı kabul edildi. Hasta gruplarının özelliklerinin karşılaştırmalarında ki-kare ve Mann Whitney-U testi uygulandı.

\section{Bulgular}

Hastaların medyan yaşı 52 $\pm 11,6$ yıl idi. Olguların klinik ve patolojik özellikleri Tablo 1'de özetlenmiştir.

Hastaların tanı anıdaki serum MMP 2-7-9, TIMP 1, IL 6-8 ve VEGF seviyeleri ve cut-off değerleri Tablo 2'de tanımlanmıştır. Hastalar evre I-II-III olanları "non-metastatik" ve evre IV olanları "metastatik" şeklinde iki gruba ayrıldı. Hasta gruplarına göre düşük-yüksek serum MMP 2-7-9, TIMP 1, IL 6-8 ve VEGF seviyeleri Tablo 3'de karşılaştırılmıştır.

Hastaların tanı anıdaki serum MMP 2-7-9, TIMP 1, IL 6-8 ve VEGF seviyeleri ile anlamlı istatistiksel ilişki saptanan klinik, laboratuar ve patolojik özellikler Tablo 4'de gösterilmiştir. Ayrıca serum CA 15-3 seviyesinde yükselme, artmış MMP 9 ve IL 6 seviyeleri ile anlamlı ilişki bulundu (sırasıly $p=0,032$ ve $p=0,008$ ). Serum LDH seviyesi artmış hastalarda serum VEGF ve TIMP 1 seviyeleri anlamlı artışa sahipti (sırasıyla $p=0,008$ ve $p=0,014$ ). Hormon pozitif grupta hormon negatif gruba göre serum MMP 7 seviyeleri anlamlı oranda düşük saptandı $(p=0,039)$. Serum MMP2 düzeyi artışı ile HER2 pozitifliği arasında istatistiksel anlamlı ilişki bulundu $(p=0,006)$ (Tablo-4).

Serum VEGF seviyeleri klinik progresyon gelişen hastalarda yüksek saptandı $(p=0,01)$. İlem sırasında exitus olan hastaların serum VEGF seviyesi daha yüksek olmakla beraber istatistiksel anlama sahip değildi $(p=0,095)$.

\section{Tartışma}

$\mathrm{Bu}$ çalışmada serum VEGF değerleri metastatik, lenf nodu pozitif, HER2 pozitif, CRP ve LDH değerleri yüksek hasta gruplarında anlamlı artış göstermiştir. Serum MMP2 ve MMP7 düzeyi artışları ile HER2 pozitifliği arasında ve ki67 oranı ile serum TIMP1 arasındaki anlamlı korelasyon saptanmıştır.

İmmünohistokimyasal olarak MMP 2 pozitifliği lenf nodu metastazı, invazyon derinliği ve uzak metastaz ile ilişkilidir [3]. Meme kanseri olgularında tümör dokusundaki MMP 2-7-9 ve TIMP 1-2 seviyeleri normal dokudan yüksek saptanmış, hastalar arası değerlendirmede ise tümör çapı artışı ve metastatik lenf nodu sayısı artışı ile MMP 2-7-9 belirteç seviyeleri istatistiksel artış göstermiştir [16]. Çalışmamızda MMP 2 seviyesi metastatik ve non-metastatik hasta gruplarında farklılık göstermemiştir. Ancak çalışmamız serum MMP 2 seviyesi artışı ile meme kanserinde olumsuz prognostik faktör olan HER2 pozitifliği arası istatistiksel anlamlı ilişki olduğunu gösteren literatürdeki ilk çalışmadır. 
Tablo1. Hastaların klinik ve patolojik özellikleri.

\begin{tabular}{|c|c|c|c|}
\hline \multicolumn{2}{|l|}{ Klinikopatolojik özellikler } & \multirow{2}{*}{$\begin{array}{r}\text { Sayı (n) } \\
7\end{array}$} & \multirow{2}{*}{$\frac{\text { Oran }(\%)}{9,0}$} \\
\hline Evre & 1 & & \\
\hline & 2 & 22 & 28,2 \\
\hline & 3 & 33 & 42,3 \\
\hline Non-metastatik & $1+2+3$ & 62 & 79,5 \\
\hline Metastatik & 4 & 16 & 20,5 \\
\hline \multirow[t]{2}{*}{ Lenf nodu tutulumu } & Yok & 23 & 29,5 \\
\hline & Var & 55 & 70,5 \\
\hline \multirow[t]{2}{*}{ Östrojen reseptör } & $(+)$ & 51 & 65,4 \\
\hline & $(-)$ & 27 & 34,6 \\
\hline \multirow[t]{2}{*}{ Progesteron reseptör } & $(+)$ & 49 & 62,8 \\
\hline & $(-)$ & 29 & 37,2 \\
\hline \multirow[t]{3}{*}{ Ki-67 } & $<20$ & 18 & 23,1 \\
\hline & $20-40$ & 43 & 55,1 \\
\hline & $40<$ & 17 & 21,8 \\
\hline \multirow[t]{2}{*}{ HER2 } & $0-1-2(+)$ & 30 & 38,5 \\
\hline & $3(+)$ & 48 & 61,5 \\
\hline \multirow[t]{2}{*}{ Progresyon } & Yok & 74 & 94,9 \\
\hline & Var & 4 & 5,1 \\
\hline \multirow[t]{2}{*}{ Son durum } & Sağ & 72 & 92,3 \\
\hline & Ex & 6 & 7,7 \\
\hline
\end{tabular}

Tablo 2. MMP 2-7-9, TIMP 1, IL 6-8 ve VEGF seviyelerinin istatistiksel verileri.

\begin{tabular}{lrrrrrr}
\hline & Mean & Std. Deviyasyon & Median & Minimum & Maksimum & Cutoff $(\mathrm{ng} / \mathrm{ml})$ \\
\hline VEGF & 2217,238 & 38,7732 & 2205,982 & 2155,7 & 2364,3 & 2209 \\
IL8 & 2,24163 &, 228517 & 2,27850 &, 990 & 2,367 & 2,28 \\
IL6 & 314,790 & 34,1864 & 318,126 & 22,9 & 331,9 & 317,4 \\
TIMP1 & 1926,641 & 1615,3551 & 1556,164 & 43,1 & 6310,6 & 1700 \\
MMP9 & 10597,438 & 1370,5394 & 10863,268 & 646,9 & 12755,8 & 10800 \\
MMP7 & 8336,568 & 1327,0824 & 8480,618 & 85,2 & 9554,7 & 8480 \\
MMP2 & 9070,143 & 132,0618 & 9015,110 & 8874,0 & 9396,3 & 8970 \\
\hline
\end{tabular}


Tablo 3. Non-metastatik ve metastatik hasta gruplarının MMP 2-7-9, TIMP 1, IL 6-8 ve VEGF seviyeleri açısından değerlendirilmesi.

\begin{tabular}{|c|c|c|c|c|}
\hline & & Metastatik (n) & Non-metastatik (n) & $p$ \\
\hline \multirow[t]{2}{*}{ MMP2 } & Düşük & 4 & 16 & 0,612 \\
\hline & Yüksek & 12 & 46 & \\
\hline \multirow[t]{2}{*}{ MMP7 } & Düşük & 8 & 31 & 0,610 \\
\hline & Yüksek & 8 & 31 & \\
\hline \multirow[t]{2}{*}{ MMP9 } & Düşük & 6 & 32 & 0,234 \\
\hline & Yüksek & 10 & 30 & \\
\hline \multirow[t]{2}{*}{ TIMP1 } & Düşük & 6 & 35 & 0,142 \\
\hline & Yüksek & 10 & 27 & \\
\hline \multirow[t]{2}{*}{ IL-6 } & Düşük & 6 & 28 & 0,397 \\
\hline & Yüksek & 10 & 34 & \\
\hline \multirow[t]{2}{*}{ IL-8 } & Düşük & 6 & 35 & 0,142 \\
\hline & Yüksek & 10 & 27 & \\
\hline \multirow[t]{2}{*}{ VEGF } & Düşük & 4 & 33 & 0,04 \\
\hline & Yüksek & 12 & 29 & \\
\hline
\end{tabular}

$p<0,05$ istatistiksel anlamlıdır

Tablo 4. Serum MMP 2-7-9, TIMP 1, IL 6-8 ve VEGF seviyeleri ile anlamlı istatistiksel ilişki saptanan klinik, laboratuar ve patolojik özellikler.

\begin{tabular}{|c|c|c|c|c|}
\hline & & CRP normal & CRP yüksek & $p$ \\
\hline \multirow[t]{2}{*}{ MMP 7} & Düşük & 39 & 0 & 0,027 \\
\hline & Yüksek & 34 & 5 & \\
\hline \multirow[t]{2}{*}{ IL 8} & Düşük & 41 & 0 & 0,021 \\
\hline & Yüksek & 32 & 5 & \\
\hline \multirow[t]{3}{*}{ VEGF } & Düşük & 37 & 0 & 0,035 \\
\hline & Yüksek & 36 & 5 & \\
\hline & & LDH normal & LDH yüksek & \\
\hline \multirow[t]{3}{*}{ VEGF } & Düşük & 37 & 0 & 0,004 \\
\hline & Yüksek & 38 & 8 & \\
\hline & & HER2 0-1-2+ & HER2 3+ & \\
\hline \multirow[t]{2}{*}{ MMP 2} & Düşük & 13 & 7 & 0,006 \\
\hline & Yüksek & 17 & 41 & \\
\hline \multirow[t]{2}{*}{ MMP 7} & Düşük & 19 & 20 & 0,05 \\
\hline & Yüksek & 11 & 28 & \\
\hline \multirow[t]{3}{*}{ VEGF } & Düşük & 18 & 19 & 0,04 \\
\hline & Yüksek & 12 & 29 & \\
\hline & & Lenf nodu (+) & Lenf nodu (-) & \\
\hline \multirow[t]{3}{*}{ VEGF } & Düşük & 21 & 16 & 0,001 \\
\hline & Yüksek & 34 & 7 & \\
\hline & & TIMP 1 düşük & TIMP 1 yüksek & \\
\hline \multirow[t]{3}{*}{ Ki67 } & $<20$ & 6 & 12 & 0,011 \\
\hline & $20-40$ & 21 & 22 & \\
\hline & $40<$ & 14 & 3 & \\
\hline
\end{tabular}

$p<0,05$ istatistiksel anlamlıdı 
Jian ve ark. MMP 7 eliminiasyonunun tümör büyümesi ve invazyon özelliğini azalttığını göstermiştir [17]. Wang ve ark. ise MMP 7 aşırı ekspresyonunun hücre invazivliğini arttırdığını, proMMP 2 ve MMP 9 aktivitesini tetiklediğini bildirmişlerdir [18]. Çalışmamızda MMP 7 yüksekliği ile CRP yüksekliği ve HER2 pozitifliği arasında anlamlı ilişki bulunmuştur. Serum CRP seviyesi artışı inflamatuvar yolak ile kanser patogenezi arasındaki ilişkiyi önceki birçok çalışma ile tutarlı olarak desteklemektedir.

Meme kanseri kötü prognozu ve tümör agresifliği ile MMP 9 ekspresyonu arasındaki ilişki önceki raporlarda gösterilmiştir [16]. Ancak çalışmamızda MMP 9 ile klinik, laboratuar ve patolojik özellikler arasında anlamlı ilişki bulunamamıştır.

Tümör invazyonunda TIMP'in etkisi MMP inhibisyonu yaparak anti-invaziv ve antimetastatik olarak etki göstermektir [19]. Çalışmamızda olguların ki67 oranı artışı ile serum TIMP1 seviyeleri istatistiksel olarak anlamlı azalma göstermektedir. Literatürde serum TIMP 1 seviyesi ile ki67 oranı ile ilgili çalışma bulunmamakla birlikte, Nakopoulou ve ark. çalışmalarında meme kanseri hücrelerinde immünohistokimyasal olarak TIMP 1 ile Ki67 oranı arasındaki ters orantıyı tanımlamışlardır [19].

Meme kanserinde serum IL 6 seviyesi yüksekliğinin olumsuz prognostik bir faktör olduğu yapılan çalışmalarda gösterilmiştir [1315]. Çalışmamızda hasta grupları arasında serum IL 6 seviyesi farkı saptanmamıştır. Ancak meme kanseri izleminde takip edilen tumor belirteçlerinden Ca 15-3 artışı ile serum IL 6 artışı arasında istatistiksel anlamlı ilişki bulunmuştur. Bu sonuç Lam ve ark. tarafından metastatik meme kanserli hastalarda yapılan çalışma sonucu ile uyumludur [20].

Serum IL-8 seviyesi artışı Ma ve ark. çalışmasında meme kanserli olgularda progresyonu arttırmaktadır [13]. Çalışma gruplarımız arasında IL 8 seviyesi farkı bulunmamakla birlikte serum CRP seviyesi artışı ile IL 8 seviyesi arasında anlamlı artış mevcuttur. Bu durum IL 8'in proenflamatuvar bir sitokin olması ile ilişkilendirilmiştir.

Serum VEGF seviyesinin birçok kanser türününde prognoz ve sağ kalım ile ilişkisi ortaya konmuştur [21]. Çalışmamızda literatür ile uyumlu olarak metastatik grup serum VEGF seviyeleri non-metastatik gruba göre istatistiksel anlamlı fark göstermiştir. Meme kanseri prognozunun temel belirleyicisi lenf nodu tutulumu ile de serum VEGF seviyesi anlamlı ilişkilidir. Çalışmamızda ayrıca hücre turn-overi ile ilişkili yüksek serum LDH seviyesi de yüksek serum VEGF seviyesi ile anlamlı korelasyon göstermiştir. Literatürde meme kanserli dokularda VEGF seviyesinin üçlü negatif ve HER2 negatif gruplara göre HER2 pozitif grupta daha yüksek olduğu bildirilmiştir. Çalışmamızda da HER2 pozitif grupta serum VEGF seviyeleri anlamlı yüksek bulunmuştur.

Sonuç olarak çalışmamız serum MMP2 düzeyi artışı ile HER2 pozitifliği arasındaki ilişkiyi ve ki67 ile serum TIMP1 arasındaki ters orantıyı literatürde ilk ortaya koyan çalışmadır. Çalışmamız kısıtlı hasta sayısına sahip bir ön çalışma özelliğinde olup yeni biyobelirteçlerin meme kanseri prognozundaki potansiyel değerlerini ortaya koymaktadır.

Çıkar İlişkisi: Yazarlar çıkar ilişkisi olmadığını beyan eder.

\section{Kaynaklar}

1) Torre LA, Bray F, Siegel RL, Ferlay J, Lortet-Tieulent J, Jemal A. Global cancer statistics, 2012. CA Cancer J Clin 2015;65:87-108. https://dx.doi.org/10.3322/ caac. 21262

2) Shim KN, Jung SA, Joo YH, Yoo K. Clinical significance of tissue levels of matrix metalloproteinases and tissue inhibitors of metalloproteinases in gastric cancer. J Gastroenterol 2007;42:120-128. https://dx.doi. org/10.1007/s00535-006-1975-y

3) Curran S, Murray GI. Matrix metalloproteinase in tumour invasion and metastasis. J Pathol 1999;189:300$308 . \quad$ https://dx.doi.org/10.1002/(SICI)10969896(199911)189:3<300::AID-PATH456>3.0.CO;2-C

4) Monig SP, Baldus SE, Hennecken JK, et al. Expression of MMP-2 is associated with progression and lymph node metastasis of gastric carcinoma. Histopathology 2001;39:597-602. https://dx.doi.org/10.1046/j.13652559.2001.01306.x

5) PasslickB, SienelW, Seen-Hibler R, etal.Overexpression of matrix metalloproteinase 2 predicts unfavorable outcome in early-stage non-small cell lung cancer. Clin Cancer Res 2000;6:3944-3948.

6) Pyke C, Ralfkiaer E, Tryggvason K, Dano K. Messenger RNA for two type IV collagenase is located in stromal cells in human colon cancer. Am J Pathol 1993;142:359365. 
7) Stetler-Stevenson WG, Krutzsch HC, Liotta LA. Tissue inhibitors of metalloproteinase (TIMP-2). A new member of the metalloproteinase inhibitor family. J Biol Chem 1989;264:17374-17378.

8) Parsons SL, Watson SA, Brown PD, Collins HM, Steele RJ. Matrix metalloproteinases. Br J Surg 1997;84:160166.

9) Coussens LM, Fingleton B, Matrisian LM. Matrix metalloproteinase inhibitors and cancer: trials and tribulations. Science 2002;295:2387-2392. https:// dx.doi.org/10.1126/science.1067100.

10) Zeng ZS, Cohen AM, Zhang ZF, Stetler-Stevenson W, Guillem JG. Elevated tissue inhibitor of metalloproteinase 1 RNA in colorectal cancer stroma correlates with lymph node and distant metastases. Clin Cancer Res 1995;1:899-906.

11) Dethlefsen C, Hojfeldt G, Hojman P. The role of intratumoral and systemic IL-6 in breast cancer. Breast Cancer Res Treat 2013;138:657-664. https://dx.doi. org/10.1007/s10549-013-2488-z

12) Todorovic-Rakovic N, Milovanovic J. Interleukin-8 in breast cancer progression. J Interf Cytokine Res 2013;33:563-570. https://dx.doi.org/10.1089/ jir.2013.0023

13) Ma Y, Ren $Y$, Dai ZJ, Wu CJ, Ji YH, Xu J. IL-6, IL-8 and TNF- alpha levels correlate with disease stage in breast cancer patients. Adv Clin Exp Med 2017;26:421426. https://dx.doi.org/ 10.17219/acem/62120

14) Bachelot T, Ray-Coquard I, Menetrier-Caux C, Rastkha M, Duc A, Blay JY. Prognostic value of serum levels of interleukin 6 and of serum and plasma levels of vascular endothelial growth factor in hormonerefractory metastatic breast cancer patients, Brit J Cancer 2003;88:1721-1726. https://dx.doi.org/10.1038/ sj.bjc. 6600956

15) Li S, Wang L, Meng Y, Chang $Y, X u$ J, Zhang $Q$. Increased levels of LAPTM4B, VEGF and survivin are correlated with tumor progression and poor prognosis in breast cancer patients. Oncotarget 2017;8:4128241293. https://dx.doi.org/10.18632/oncotarget.17176

16) Zhang M, Teng X, Guo X, Li Z, Han J, Yao L. Expression of tissue levels of matrix metalloproteinases and their inhibitors in breast cancer. Breast 2013;22:330-334. https://dx.doi.org/10.1016/j.breast.2012.08.002

17) Jian WG, Davies G, Martin TA, et al. Targeting matrilysin and its impact on tumor growth in vivo: the potential implications in breast cancer therapy. Clin Cancer Res 2005;11:6012-6019. https://dx.doi.org/10.1158/10780432.CCR-05-0275

18) Wang F, Reierstad S, Fishman DA. Matrilysin overexpression in MCF-7 cells enhances cellular invasiveness and pro-gelatinase activation. Cancer Lett 2006;236:292-301. https://dx.doi.org/10.1016/j. canlet.2005.05.042
19) Nakopoulou L, Giannopoulou I, Lazaris A, et al. The favorable prognostic impact of tissue inhibitor of matrix metalloproteinases-1 protein overexpression in breast cancer cells. APMIS 2003;111:1027-1036. https:// dx.doi.org/10.1111/j.1600-0463.2003.apm1111105.x

20) Lam SW, Nota NM, Jager A, et al. Angiogenesis- and hypoxia-associated proteins as early indicators of the outcome in patients with metastatic breast cancer given first-line bevacizumab-based therapy. Clin Cancer Res 2016;22:1611-1620. https://dx.doi.org/10.1158/10780432.CCR-15-1005

21) Degirmencioglu S, Ugurlu E, Yaren A. Clinical significance of serum vascular endothelial growth factor levels in patients with advanced non-small cell lung cancer. World J Oncol Res 2017;4:7-11. https:// dx.doi.org/10.15379/2413-7308.2017.04.02

15-18 Şubat 2018 tarihleri arasında Antalya Barut Otel Lara'da düzenlenen Gençlerle onkolojiye bakış kongresinde sözlü bildiri olarak sunulmuştur. 